\title{
Saylor, Alexander and Lewis's Curriculum Development Model for Islamic Education in Schools
}

\author{
Mardhiyah Taufik $^{1}$, Endis Firdaus ${ }^{1}$ \\ ${ }_{1}^{1}$ Pendidikan Agama Islam, Sekolah Pascasarjana, Universitas Pendidikan Indonesia, Bandung, Indonesia
}

\section{ARTICLE INFO}

\section{Keywords}

Curriculum Development, Islamic Education, Schools

\section{*Correspondence maree17@upi.edu}

\section{Article History \\ Received 25 March 2021 \\ Accepted 06 July 2021 \\ Published online 07 July 2021}

\section{ABSTRACT}

This study aims to identify the curriculum development model by Saylor, Alexander, and Lewis for Islamic education and its implications in schools. This study applied qualitative approach and literature study methods. The results of this study indicate that the curriculum is in line with the times. The curriculum also develops to meet the demands of current education systems. To achieve a goal in the educational process requires a design in implementation. Therefore, the curriculum is a design in which there are systematically designed programs to set a goal. Saylor, Alexander, and Lewis consider curriculum as the efforts of schools to influence students to learn, both in the classroom, on the schoolyard, and outside the school. Therefore, there are various demands that Islamic education must be able to answer those needs. Islamic Education is a vast subject in schools. It needs to be selected for its material and developed according to the needs and competencies of students and has use of value for students. Systematically, this paper implies that it tries to provide an overview of the Saylor, Alexander, and Lewis curriculum models and can guide carrying out activities and their implementation in Islamic education.

\section{PENDAHULUAN}

Jika kita mempelajari buku-buku atau literatur lainnya tentang kurikulum yang berkembang saat ini, terutama yang berkembang di negara-negara maju maka kita akan menemukan banyak pengertian yang lebih luas dan beragam. Kurikulum tidak terbatas hanya pada sejumlah mata pelajaran saja, tetapi mencakup semua pengalaman belajar (learning experiences) yang dialami siswa dan mempengaruhi perkembangan pribadinya. Bahkan Harold B. Alberty dan Elsie J. Alberty memandang kurikulum sebagai semua kegiatan yang diberikan kepada siswa di bawah tanggung jawab sekolah (all of the activities that are provided for the students by the school). Kurikulum tidak dibatasi pada kegiatan di dalam kelas saja, tetapi mencakup juga kegiatan-kegiatan yang dilakukan oleh siswa di luar kelas. Pendapat yang senada dan menguatkan pengertian tersebut dikemukakan oleh Saylor, Alexander, dan Lewis (1974) yang menganggap kurikulum sebagai segala upaya sekolah untuk mempengaruhi siswa supaya belajar, baik dalam ruangan kelas, di halaman sekolah, maupun di luar sekolah (the curriculum is the sum total of school's efforts to influence learning, whether in the classroom, on the playground, or out of school).

Kurikulum adalah seperangkat rencana dan pengaturan mengenai isi dan bahan pelajaran serta cara yang digunakan sebagai pedoman penyelenggaraan kegiatan pembelajaran untuk mencapai tujuan pendidikan tertentu. (Undang-Undang No.20 TH. 2003 Tentang Sistem Pendidikan Nasional). Kurikulum adalah serangkaian mata ajar dan pengalaman belajar yang mempunyai tujuan tertentu, yang diajarkan dengan cara tertentu dan kemudian dilakukan evaluasi. (Badan Standardisasi Nasional SIN 19-7057- 2004 tentang Kurikulum Pelatihan Hiperkes dan Keselamatan Kerja Bagi Dokter Perusahaan) (Widodo Winarso, 2015).

Pada hakikatnya kurikulum sebagai suatu program kegiatan terencana (program of planned activities) yang memiliki rentang yang cukup luas, hingga membentuk suatu pandangan yang menyeluruh. (Hamalik, 2016). Kurikulum senantiasa bersifat dinamis guna lebih menyesuaikan dengan berbagai perkembangan yang terjadi. Setiap pendidik harus memahami perkembangan kurikulum, karena merupakan suatu formulasi pedagogis yang paling penting dalam konteks pendidikan, dalam kurikulum tergambar bagaimana usaha yang dilakukan membantu siswa dalam mengembangkan potensinya, berupa fisik, intelektual, emosional, social, keagamaan dan sebagainya. (Ramayulis, 2015). Allah SWT Berfirman di dalam Q.S. Ali Imran/3: 104:

Artinya: "Dan hendaklah ada di antara kamu segolongan umat yang menyeru kepada kebajikan, menyuruh kepada yang ma'ruf dan mencegah dari yang munkar merekalah orangorang yang beruntung."

Dari ayat diatas segolongan umat hendaklah menyeru dalam kebajikan, menyuruh yang ma'ruf dan mencegah perkara yang mungkar diartikan lebih mendalam sebagai tugas guru khususnya guru PAI. Ramayulis menuliskan dalam bukunya ada beberapa

(c) 2021 by the authors; licensee PRIMA, Hannover, Germany. This is an Open Access article distributed under the terms of the Creative Commons Attribution-ShareAlike 4.0 International License. (https://creativecommons.org/licenses/by-sa/4.0/), which permits unrestricted use, distribution, and reproduction in any medium, provided the original work is properly cited. 
teknik mengajar guru PAI, yaitu mendidik melalui keteladanan, mendidik melalui kebiasaan, mendidik melalui nasihat dan cerita, mendidik melalui disiplin, mendidik melalui partisipatif, dan mendidik melalui pemeliharaan (Mutmainah \& Mufid, 2018).

PAI di sekolah memiliki beberapa komponen, yaitu pendidik, peserta didik, lingkungan pendidikan, alat pendidikan, metode dan evaluasi. Sedangkan wadah dari semua itu adalah kurikulum. Menurut Undang-Undang Nomor 20 Tahun 2003 tentang sistem Pendidikan Nasional, Kurikulum adalah seperangkat rencana dan pengaturan mengenai, tujuan, isi, dan bahan pelajaran, serta cara yang digunakan sebagai pedoman penyelenggaraan kegiatan pembelajaran untuk mencapai tujuan pendidikan tertentu" (Bab 1 pasal 1 ayat 19). Untuk mengetahui seberapa baik PAI yang diterapkan oleh sekolah dapat dilihat dari keberjalanan kurikulum PAI sekolah itu sendiri. Menurut Mulyasa, "Melalui kurikulum 2013 diharapkan akan menghasilkan peserta didik yang produktif, kreatif, inovatif, afektif melalui penguatan sikap, keterampilan, dan pengetahuan yang terintegrasi. Dalam hal ini, pengembangan kurikulum difokuskan pada pembentukan kompetensi dan karakter peserta didik, berupa panduan pengetahuan, keterampilan dan sikap yang dapat didemontrasikan peserta didik sebagai wujud pemahaman terhadap konsep yang dipelajari secara kontekstual," (Kusumastuti \& Lisnawati, 2013).

Adapun kurikulum pendidikan di Negara Jerman dapat diformulasikan sebagai berikut: a). Tujuan umum kurikulum ditentukan oleh peraturan sekolah/sering dinyatakan pada mukaddimah suatu keputusan, sedangkan tujuan khusus diterbitkan dalam kaitannya dengan pedoman kurikulum; b). Silabus, rekomendasi metode mengajar dan model rencana pelajaran diputuskan oleh kementrian negara; c). Mengenai buku teks, tidak ada yang dapat dipakai tanpa ada persetujuan dari kementerian negara bagian dan guru boleh menggunakannya sejauh terdapat dalam daftar rekomendasi buku yang sah; d). Metode mengajar, bukan "teacher centered" tetapi "student centered" yang sifatnya "open instruction" (murid belajar atas dorongan sendiri)(Isri, 2015).

Secara falsafi, landasan sistem pendidikan Jerman dengan Indonesia memiliki banyak kesamaan. Hal ini terjadi karena pendidikan di manapun adalah hal yang dianggap baik. Namun dari beberapa persamaan landasan pendidikan Indonesia dan Jerman dalam praktek pelaksanaan pendidikan ada perbedaan misalnya masalah Sentralisasi dan desentralisasi pendidikan di Indonesia masih merupakan pembicaraan yang melibatkan banyak perbedaan pemahaman. Persamaan persepsi antara masyarakat dengan pemerintah sebagai pembuat kebijakan pendidikan di Indonesia belum terwujud dengan baik berbeda dengan Jerman. Sistem pendidikan tinggi (universitas) di jerman mengakomodasi mereka yang menginginkan "kebebasan" untuk mengatur Studi mereka, hal ini mendorong kemadirian untuk memprogram belajar sesuai bidang yang diminati, sementara di Indonesia jarang ada yang demikian (Isri, 2015).

Di Amerika Serikat pemegang kekuasaan sosial-politik yang menentukan kebijaksanaan dalam kurikulum adalah board of local education yang mewakili negara bagian. Di Indonesia, pemegang kekuasaan sosial politik dalam penentuan kurikulum adalah Menteri Pendidikan Nasional yang dalam pelaksanaannya dilimpahkan kepada Dirjen Pendidikan Dasar dan Menengah serta Dirjen Pendidikan Tinggi bekerja sama dengan Balitbang Diknas atau kalau di Departemen Agama dalam pelaksanaannya dilimpahkan kepada Direktur Pendidikan Madrasah dan Ditperta atau Dirjen Pendidikan Islam yang bertanggung jawab langsung kepada Menteri Agama. Dengan adanya Disentralisasi, maka disinilah masing-masing lembaga atau daerah mempunyai otoritas dalam penyusunan kurikulum (Nur Ahid, 2006). Sebab-sebab perubahan kurikulum diantaranya karena derasnya arus informasi, tuntutan kehidupan masyarakat, serta situasi politik di suatu Negara sehingga menyebabkan kurikulum yang ada perlu adanya pengembangan. Berdasarkan realita ini, kurikulum yang ada memerlukan inovasi-inovasi atau kolaborasi guna menunjang proses pendidikan.

Istilah-istilah kurikulum dapat dijadikan acuan untuk menentukan bentuk kurikulum mana yang akan disusun. Perbedaan istilah yang dipegang dapat berimplikasi terhadap perbedaan bentuk kurikulum itu sendiri. Berbagai macam perbedaan tentang kurikulum tersebut lahir karena adanya berbagai perbedaan konsep tentang fungsi sekolah. Menurut Hilda Taba, fungsi pendidikan di sekolah dapat diklasifikasikan menjadi tiga jenis, yaitu : 1) sebagai pemelihara dan pentransmisi budaya, 2) sebagai pentransformasi budaya, dan 3) sebagai pengembang pribadi anak. Namun, ada beberapa perbedaan pendapat para ahli terkait dengan kurikulum, ada yang menekankan pada isi menjadi lebih memberikan tekanan pada pengalaman belajar, dan ada juga yang menekankan pada proses. Di era yang serba modern ini dengan spesifikasi tertentu, sangat besar pengaruhnya terhadap dunia pendidikan. Perubahan-perubahan yang dapat terjadi selain karena perkembangan teknologi yang sangat pesat, juga diakibatkan oleh perkembangan yang luar biasa dalam ilmu pengetahuan (Budianto, 2019).

Permasalahan lain yang melatarbelakangi adanya inovasi kurikulum yang mana merupakan bagian dari dialektika politik kekuasaan dan kepentingan. Kurikulum menjadi mesin politik kekuasaan untuk melancarkan segala program penguasa. Kurikulum bukan lagi membincangkan dan mencerminkan kebutuhan-kebutuhan sosial di tengah-tengah masyarakat. Bukan lagi cerminan bagaimana sesungguhnya peserta didik harus belajar dan mempelajari kehidupan sesuai dengan kebutuhan lingkungan. Dengan demikian, kurikulum dan kekuasaan merupakan paket yang dirancang sedemikian rupa oleh para penguasa (Tatang Hidayat, 2019).

Berdasarkan permasalahan di atas, perlu adanya solusi untuk menyelesaikannya, dalam hal ini bagaimana kurikulum yang ada untuk dikembangankan, salah satunya dalam pembelajaran Pendidikan Agama Islam (PAI). Dari sekian banyak model pengembangan kurikulum yang ada, model pengembangan kurikulum Saylor, Alexander, dan Lewis diharapkan mampu menjadi cerminan sebagai wujud pemahaman dan menjadi pengalaman belajar peserta didik terhadap konsep yang dipelajari secara konstekstual dan tepat, apalagi terhadap PAI. Seseorang yang menganut konsep kurikulum yang sempit, akan mengarahkan kepada perkembangan kurikulum yang berpusat pada upaya untuk "mentransfer" sebanyak mungkin materi pelajaran kepada peserta didiknya. Tetapi seringkali kurang peduli apakah transfer materi itu dapat dipahami peserta didik secara penuh atau tidak. Sebaiknya seseorang yang menganut konsep yang luas, perkembangan kurikulum lebih diarahkannya pada upaya pemberdayaan peserta didik agar mampu secara aktif dan mandiri mempelajari materi pelajaran itu di luar kelas bahkan di luar sekolah. Kurikulum tidak cukup berupa materi pelajaran saja, tetapi haruslah menjangkau lebih jauh dari itu yaitu pengalaman belajar (learning experience) peserta didik sebagai hasil proses pembelajaran berdasarkan kurikulum formal tersebut (Lase \& Nias, 2015).

Dengan memahami kurikulum, para pendidik dapat memilih dan menentukan tujuan pembelajaran, metode, tehnik, media pengajaran, dan alat evaluasi pengajaran yang sesuai dan tepat. Untuk itu, dalam melakukan kajian terhadap keberhasilan sistem pendidikan ditentukan oleh semua pihak, sarana dan organisasi yang baik, intensitas pekerjaan yang realistis tinggi dan kurikulum yang tepat guna. Aplikasi model Saylor, Alexander, dan Lewis ini diharapkan dapat mengkonstruk model kurikulum berbasis deduktif, karena karakteristik pemikiran pengembangan kurikulum Saylor, Alexander, dan Lewis ialah bersifat dari umum ke khusus yang mana suatu rencana berisi sekumpulan pengalaman belajar untuk peserta didik yang akan dididik, dalam arti memberikan peluang sebesar-besar kepada guru untuk ikut serta dalam merancang kurikulum. Sehingga timbul pertanyaan 
bagaimana implikasi model pengembangan kurikulum Saylor, Alexander, dan Lewis dalam PAI di sekolah? Untuk menjawab pertanyaan ini maka diperlukan sebuah peneliti.

\section{METODE PENELITIAN}

Dalam kajian ini penulis menggunakan metode studi literatur. Studi literatur merupakan metode penelitian dengan menggunakan sumber dari karya tulis terpublikasi. Hasil dari artikel ini merupakan pengkajian dari beberapa karya tulis mengenai model kurikulum Saylor, Alexander dan lewis. Metode kajian pustaka ini digunakan untuk mengumpulkan berbagai informasi dan datadata. Diperlukan langkah-langkah seperti mengumpulkan referensi yang sesuai dengan kajian yang akan dibahas, mencari pembahasan yang sesuai dan berhubungan dengan materi penulisan artikel ini, serta menganalisis isi dari sumber-sumber yang telah didapatkan. Sumber-sumber yang dapat digunakan dalam kajian pustaka antara lain ialah jurnal, buku, skripsi/tesis, atau hasil penelitian orang lain yang telah terpublikasi.

\section{HASIL DAN PEMBAHASAN}

Kata kurikulum mendapat banyak penafsiran dari berbagai pakar dalam bidang pengembangan kurikulum dari dulu sampai saat ini. Interpretasi tersebut terdapat banyak sekali perbedaan sesuai dengan pandangan masing-masing pakar dan disesuaikan dengan titik berat inti yang para pakar kaji (Hamalik, 1994). Kurikulum juga dapat diartikan sebagai sebuah rencana menganai tujuan belajar, kompetensi yg ingin dicapai, materi dan hasil belajar yg diharapkan sebagai landasan dan pedoman untuk mencapai kompetensi mendasar dan tujuan dari pendidikan (Wafi, 2017).

Curriculum can be defined in many ways: as the teaching and learning of pedagogy and of subject-matter content (Adler, 1991); as a plan, in terms of experiences or as a field of study that relates to subject matter and grade levels (Lunenburg \& Ornstein, 2000); as the educative experiences learners have in an educational planned program based on a framework of theory and research, past and present professional practice, and the changing needs of society (Parkay, Anctil \& Hass, 2006); as a program; courses or a discipline (a subject of study) based on an organized set of principles, a body of knowledge and skills, and theoreticians and practitioners (Oliva, 2009) (Daud et al., 2012).

Berdasarkan pernafsiran berbagai pakar diatas, kurikulum dapat diartikan sebagai pembelajaran dari ilmu pendidikan dan memiliki suatu gagasan dari suatu materi. Sebagai sebuah rencana terhadap pengalaman atau bahan ajar yang memiliki hubungan dengan konsep yang dipelajari. Tidak bisa disangkal bahwa kurikulum berkembang terus dari tahun ke tahun seiring dengan perkembagan ilmu dan teknologi. Seorang pendidik pernah berkata dalam (Kusumaningrum, 2001): "Jika kita tidak mengikuti perkembangan teknologi yang berkembang dengan sangat cepat ini, diperkirakan dua puluh tahun ke depan kita akan menjadi manusia purba". Perkataan ini mengandung kebenaran, bahwa para pendidik dituntut untuk meningkatkan terus kemampuannya dalam merencanakan dan melaksanakan pembelajaran. Begitu juga kurikulum harus dikembangkan seiring dengan perkembangan ilmu dan teknologi. Kalau tidak, akan tertinggal dengan bangsabangsa lain di dunia ini (Lase \& Nias, 2015).

Pengembangan kurikulum mempunyai makna yang cukup luas, menurut Nana Syaodih Sukmadinata pengembangan kurikulum bisa berarti penyusunan kurikulum yang sama sekali baru (curriculum construction), bisa juga menyempurnakan kurikulum yang telah ada (curriculum improvement). Good dan Travers dalam Sanjaya, model adalah abstraksi dunia nyata atau representasi peristiwa kompleks atau sistem, dalam bentuk naratif, matematis, grafis, serta lambang-lambang lainnya. Model bukan realitas, akan tetapi merupakan representasi realitas yang dikembangkan dari keadaan. Dengan demikian, model pada dasarnya berkaitan dengan rancangan yang dapat digunakan untuk menerjemahkan sesuatu ke dalam realitas, yang bersifat praktis. Model berfungsi sebagai sarana untuk mempermudah berkomunikasi, atau sebagai pentunjuk yang bersifat perspektif untuk mengambil keputusan, atau sebagai petunjuk perencanaan untuk kegiataan pengelolaan (Mulyana, 2018).

Dalam pengembangan kurikulum tidak dapat lepas dari berbagai faktor maupun aspek yang mempengaruhinya, seperti cara berpikir, sistem nilai (nilai moral, keagamaan, politik, budaya, dan sosial), proses pengembangan kebutuhan peserta didik, lingkup (scope) dan urutan (sequence) bahan pelajaran, kebutuhan masyarakat maupun arah program pendidikan.

Sementara pengembangan kurikulum yang dilakukan pemerintah hendaknya dapat diadaptasikan dengan budaya sekolah masing-masing dan sesuai dengan kebutuhan siswa yang memiliki latar belakang beragaman dan kekhasan masing-masing. Kurikulum merupakan salah satu kunci pendidikan. Kurikulum menjadi penentu arah, isi dan proses pendidikan, yang pada akhirnya juga menentukan kualifikasi lulusan sebuah lembaga pendidikan. Sebagai salah satu variabel yang mempengaruhi sistem pendidikan, maka kurikulum harus dapat mengikuti dinamika yang ada dalam masyarakat. Kurikulum harus bisa menjawab kebutuhan masyarakat luas dalam menghadapi persoalan kehidupan yang dihadapi (Septiana, 2019).

Berdasarkan hal di atas jelas bahwa kurikulum ialah sebagai sistem dari proses pendidikan yang bersifat luas. Kurikulum memuat tujuan, pengalaman belajar yang harus dimiliki setiap siswa serta berbagai fasilitas yang mendorongnya. Pengembangan kurikulum (curriculum development) didefiniskan sebagai a complex process of assessing needs, identifying desired learning outcomes, preparing for instruction to achieve the outcomes, and meeting the cultural, social, and personal needs that the curriculum is to serve. Artinya: "Pengembangan kurikulum adalah sebuah proses yang kompleks dalam menilai kebutuhan, mengidentifikasi hasil belajar yang diinginkan, mempersiapkan pembelajaran untuk mencapai hasil belajar, dan memenuhi kebutuhan pribadi, budaya, sosial yang harus penuhi oleh kurikulum (Nasron HK, 2017).

Dalam pendidikan formal khususnya tidak dapat terlepas dari desain kurikulum yang dikembangkan. Dalam konteks ini, pendidikan, kurikulum dan stekholder (masyarakat sekolah) sebenarnya saling terikat antara satu sama lain tidak dapat dipisahkan. Untuk mewujudkan tujuan pendidikan, memberikan sejumlah pengalaman yang direncanakan dan telah disusun dalam suatu kurikulum pendidikan formal dengan penciptaan suasana yang berlandaskan keagaamaan yang bersifat mutlak sesuai dengan tujuan hidup manusia dan peranannya sebagai ciptaan Allah.

Berdasarkan perkembangan dan pemikiran para ahli kurikulum, banyak rumusan pengertian dari istilah kurikulum yang sebenarnya ada unsur-unsur kesamaan dan perbedaan, sehingga bisa dibuat kategorisasi. Kategori rumusan pengertian kurikulum menurut Saylor, Alexander dan Lewis, yang dikutip Mohammad Ali adalah: (1) Kurikulum sebagai rencana tentang mata pelajaran atau bahan-bahan pelajaran; (2) Kurikulum sebagai rencana tentang pengalaman belajar; (3) Kurikulum, sebagai rencana tentang tujuan pendidikan yang hendak dicapai; dan (4) dan kurikulum; sebagai rencana tentang kesempatan belajar (Ali, 1921, p. 3). 


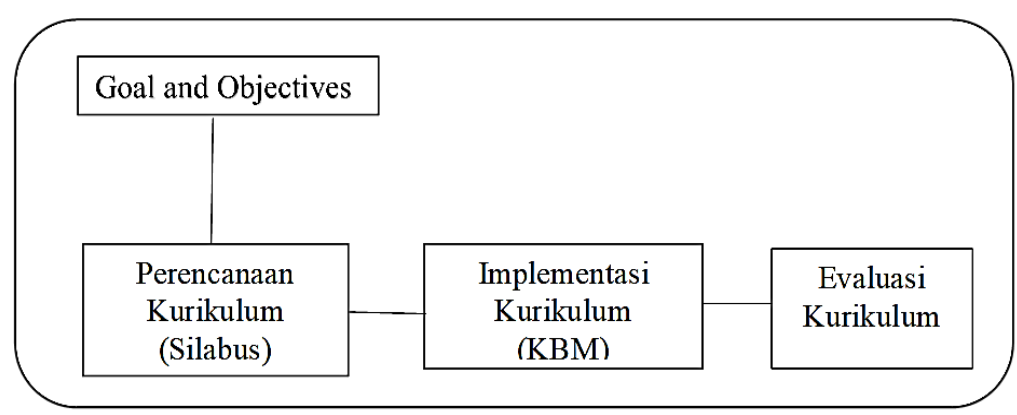

Gambar 1. Konsep Proses Perencanaan Kurikulum Saylor, Alexander, and Lewis

\begin{abstract}
Saylor, Alexander and Lewis adopt an administrative approach to their curriculum development model. This model consists of four steps; goals and objectives, curriculum design, curriculum implementation and curriculum evaluation. The goals and objectives are influenced by external forces, such as legal requirements, research data, professional associations and state guidelines. This step is also influenced by bases of curriculum, such as society, learner and knowledge. The second step of Saylor, Alexander and Lewis Model is curriculum design. In this step curriculum planners analyze the goals and objectives to create a curriculum design. The third step is curriculum implementation and this step is similar to "Performing Pilot Experiment" step. This step involves decisions about instruction which is the implementation of curriculum plan. The last step of Saylor, Alexander and Lewis Model involves the evaluation of both expected learning outcomes and the entire curriculum plan (Fred C. Lunenburg, 2011).
\end{abstract}

Menurut Saylor, Alexander, and Lewis (1981) "We define curriculum as a plan for providing sets of learning opportunities for person to be educate"(Fred C. Lunenburg, 2011). Mereka mendefinisikan kurikulum pada gambar 1 sebagai perangkat/langkah rencana yang diarahkan pada sekumpulan aktivitas pembelajaran bagi individu agar menjadi terdidik. Perencanaan kurikulum merupakan beberapa rencana unit-unit kecil pada bagian-bagian tertentu dari sebuah kurikulum.

a. Goals (tujuan) merupakaan sesuatu yang ingin di capai, yang mana terbagi menjadi dua; yaitu general goals (tujuan umum) yaitu suatu pencapaian menuju sejauh mana usaha mau diarahkan. Istilah lebih luasnya dalam dunia pendidikan untuk menentukan hasil penting yang diinginkan dari program pendidikan. Selanjutnya subgoal (tujuan khusus) lebih spesifik mengarah langsung pada tujuan yang dicari dalam kesempatan belajar

b. Curriculum Designing: Menentukan struktur kurikulum, memilih dan mengelompokkan materi, menentukan strategi kurikulum, menyusun perangkat pembelajaran, media pembelajaran, instrument evaluasi atau penilaian.

c. Curriculum Implementation: Dalam penerapan kurikulum guru diberikan pilihan strategi penyajian materi yang sudah disediakan di dalam kurikulum sesuai dengan tujuan instruksional yang hendak dicapai.

d. Curriculum Evaluation: Evaluasi kurikulum menurut Saylor, Alexander, dan Lewis terbagi ke dalam lima komponen, yaitu: Evaluasi program pendidikan sekolah: (1) goals, subgoals, objectives, (2) the program of education as a totality, (3) the specific segments of the education program, (4) instruction. Evaluasi dari program evaluasi: (5) evaluation program.

Evaluasi kurikulum memegang peranan penting baik dalam penetuan kebijaksanaan pendidikan pada umumnya, maupun pada pengambilan keputusan dalam kurikulum. Evaluasi kurikulum dimaksudkan untuk memperbaiki subsantsi kurikulum, prosedur implementasi kurikulum, metode intruksional, serta pengaruhnya pada belajar dan perilaku siswa (Adnan, 2017). Sebagaimana dijelaskan juga bahwa "The evaluation process allows curriculum planners to determine whether or not, the goals of the school and objectives of instruction have been met. Saylor, Alexander and Lewis supplemented their model of the curriculum planning process with companion models depicting the elements of the curriculum system, the process of defining the goals and objectives of educational institutions and curriculum evaluation became focal points" (Adirika \& Okolie, 2016). Saylor dan Alexander berpendapat bahwa evaluasi adalah proses pengumpulan dan penggunaan informasi sebagai dasar pembuatan keputusan tentang suatu program pendidikan. Dari pengertian evaluasi di atas, ada tiga komponen dalam evaluasi, yaitu pengumpulan informasi, pembuatan pertimbangan, dan pembuatan keputusan. Ketiga komponen evaluasi tersebut saling berkaitan satu sama lain. Karena itu, dalam proses evaluasi ketiga komponen itu harus dipahami secara jelas (Nur Ahid, 2006).

Menentukan Goals, Objectives dan domain, model ini mulai menunjukkan bahwa tujuan umum pendidikan dan tujuan khusus pendidikan yang di klasifikasikan menjadi empat domain yaitu: pengembangan diri, kompetensi social, kemampuan belajar berkesinambungan dan spesialisa (Coffman, 1981). Pinar (2008) assessing, planning and design curriculum models J. Galen Saylor, William Alexander, and Arthur Lewis are considered as traditional model most widely known. Pinar said that according to Saylor, Alexander, and Lewis, the planning and design of a rational process, based on the order, and bureaucratic. Dalam buku karangan oliva, 2013 mengatakan bahwa model pengembangan kurikulum SAL memiliki beberapa karakteristik pengembangan kurikulum yang bagus. berdasarkan pandangan komprehensif terhadap setiap kegiatan yang direncanakan, kurikulum berupaya menggabungkan ruang lingkup, rangkaian, interpretasi, keseimbangan subject matter, teknik mengajar, dan hal lain yang dapat direncanakan sebelumnya.

Dalam Saylor, Alexander, dan Lewis membagi desain kurikulum menjadi kurikulum subject matter disiplin, kompetensi yang barsifat spesifik atau kurikulum teknologi, kurikulum sebagai proses, kurikulum sebagai fungsi sosial, dan kurikulum yang berdasarkan minat individu(Yu'timaalahuyatazaka, 2016). Metode SAL dikembangkan secara deduktif, yang mana metode ini mempunyai kelebihan pada anak-anak yang masih belajar nilai pada tahap pemula, karena anak tersebut terlebih dahulu dikenalkan beberapa teori tentang nilai secara umum baru kemudian ditarik rincian yang lebih sempit dan mendetail serta dihubungkan dengan kasus-kasus yang terjadi dalam masyarakat sehingga metode ini baik untuk mengembangkan kearah pendidikan nilai ketuhanan dan nilai-nilai kemanusiaan (Mubasyaroh, 2013). 
Tujuan pendidikan di Indonesia, pada hakikatnya ingin menempatkan kedudukan manusia secara utuh yaitu manusia yang sehat jasmani dan ruhani. Untuk mencapai tujuan itu maka, proses pendidikan lebih diarahkan pada perkembangan manusia yang meliputi aspek Afektif, Kognitif dan Psikomotorik. Peserta didik memiliki kemampuan yang berbeda-beda, sehingga pelayanan proses pendidikan berpusat pada kepentingan siswa sesuai dengan minat dan bakatnya (Masykur, 2019).

Pembelajaran yang berlangsung sekarang ini kebanyakan lebih mengarah kepada pendidikan kognitif dan menghafal sehingga pengajaran sikap dan keterampilan yang menjadi salah satu kompetensi lulusan belum tercapai dengan baik (Husniyah, 2015). Dibutuhkan metode pembelajaran yang ditujukan untuk siswa agar informasi yang disampaikan oleh guru diterima jelas oleh siswa yang pada akhirnya menumbuhkan semangat siswa dalam belajar. Adapun salah satu metode yang dapat digunakan adalah metode pembelajaran di luar kelas (outdoor study). Permasalahan lainnya yang perlu diperhatikan dan digarisbawahi bahwa materi pendidikan sebenarnya tidak hanya perlu dimaknai dalam arti menguasai ilmu pengetahuan, nilai dan keterampilan sebagaimana telah dikemukakan. Pengembangan materi pendidikan Islam bukanlah sekedar untuk menggabungkan muatan materi pendidikan agama dan umum seperti yang disinggung atau banyak dilakukan banyak orang. Pemahaman seperti itu justru dapat membawa muatan kurikulum pendidikan Islam di samping sangat padat, tetapi juga mengakibatkan para siswa merasa sulit untuk mengikuti materi tersebut. Maka sebelum merumuskan kurikulum para ahli haru menyesuaikan dengan kebutuhan peserta didik dalam dunia pendidikan yang nantinya akan membangun negara dan mampu bersaing dalam ilmu pengetahuan dan membawa kedamaian. Oleh karena itu, tuntutan utama dalam pengembangan materi pendidikan Islam, bukanlah materi yang padat, lebih dari itu adalah kemampuan-kemampuan yang membawa siswa menguasai ketrampilan hidup (life skill) yang Islami. Ketrampilan-ketrampilan tersebut antara lain berhubungan dengan ketrampilan berpikir, emosi, ketrampilan sosial, politik, ibadah, olah raga, kesehatan, kesenian, hukum, ekonomi, ilmu pengetahuan, dan sebagainya. Semua ketrampilan dikembangkan lewat proses rancangan pengembangan materi di mana bangunannya diletakkan di atas konsep-konsep spiritual Islam. Inilah makna pengembangan materi pendidikan yang dimaknai sebagai profil materi pendidikan Islam (Chanifudin, 2020).

Implementasi dalam PAI ini sejalan dengan konsep perencanaan kurikulum yang di gagas Saylor, Alexander dan Lewis. Yang mana seperangkat rencana dan pengaturan mengenai tujuan, isi dan bahan pelajaran serta yang digunakan sebagai pedoman penyelenggaraan kegiatan pembelajaran untuk mencapai tujuan pendidikan agama islam, tidak hanya mencakup tujuan, bahan atau materi pembelajaran PAI saja, akan tetapi mencakup segala kegiatan yang dirancang sekolah maupun kegiatan yang dilakukan di luar sekolah, di dalam jam belajar sekolah maupun di luar jam sekolah.

Ini merupakan rancangan yang sesuai dengan tujuan pengembangan kurikulum SAL yang mana menganggap kurikulum sebagai segala upaya sekolah untuk mempengaruhi siswa supaya belajar, baik dalam ruangan kelas, di halaman sekolah, maupun di luar sekolah. Sebetulnya mereka sudah melakukan proses pembelajaran sesuai dengan tuntutan kurikulum yang terbaru untuk saat ini, yakni kurikulum 2013. Contohnya dalam mapel Pendidikan Agama Islam pada bab Fiqih pada anak tingkat sekolah menengah atas (SMA) dapat mengajak siswa untuk ikut menyolatkan jenazah ketika ada warga sekitar sekolah yang meninggal dunia, pada bab munakahat; guru mengajak siswa langsung ke tempat berlangsungnya urusan agama Islam yaitu KUA atau siswa diberi tugas untuk melihat langsung bagaimana proses rukun nikah berlangsung di sekitar tempat tinggalnya serta di dokumentasikan dalam bentuk unjuk kerja, dan di laporkan dalam bentuk portopolio atau nilai produk.

Proses belajar mengajar di luar kelas harus memiliki konsep kegiatan yang jelas yang menjadi acuan bagi guru untuk menyampaikan informasi kepada siswa, kemudian konsep penelitian dimana pembelajaran luar kelas ditekankan siswa mampu menalar dan berfikir terbuka. Konsep yang terakhir adalah konsep kekeluargaan, dengan pembelajaran di luar kelas hubungan siswa dengan siswa, siswa dengan guru akan terasa lebih kekeluargaan dibandingkan dengan pembelajaran di dalam kelas yang cenderung kaku (Astuti, 13 September 2019).

Pembelajaran di luar kelas dapat mengubah persepsi siswa terhadap lingkungan dan meningkatkan kepekaan terhadap lingkungan (Bogner, 2002). Memanfaatkan sumber belajar akan dapat membantu dan memberikan kesempatan belajar yang berpartisipan serta dapat memberikan pengalaman belajar yang kongkrit, sehingga tujuan yang telah ditentukan dapat dicapai dengan efesien dan efektif.

Dengan adanya fungsi tersebut dalam pengembangan model SAL pengalaman belajar sangat sangat berpengaruh dan berkontribusi terhadap pertumbuhan dan perkembangan belajar. Begitu juga dalam pendidikan agama Islam, pengalaman dan kebiasaan sangat mempengaruhi terhadap kesadaran individu bahwa Pendidikan Agama perlu menggunakan beberapa pendekatan itu. Kurikulum Pendidikan Agama Islam menyebutkan bahwa pendidikan agama Islam adalah untuk menumbuhkan dan meningkatkan keimanan, melalui pemberian dan pemupukan pengetahuan, penghayatan, pengalaman serta pengalaman peserta didik tentang agama Islam sehingga menjadi manusia muslim yang terus berkembang dalam hal keimanan, ketaqwaan kepada Allah SWT serta berakhlak mulia dalam kehidupan pribadi, bermasyarakat, berbangsa dan bernegara. Serta untuk dapat melanjutkan pada jenjang pendidikan lebih tinggi. Yakni memberikan pengalaman keagamaan kepada peserta didik dalam rangka penanaman nilai-nilai keagaamaan dan memberikan kesempatan kepada peserta didik untuk senantiasa mengamalkan ajaran agamanya. Bersifat menyeluruh sehingga dapat digunakan sebagai pedoman hidup dan amalan perbuatannya, baik dalam hubungan dirinya dengan Allah SWT, hubungan dirinya dengan masyarakat maupun dirinya dengan alam sekitar. Membentuk pribadi yang berakhlak mulia, sesuai dengan ajaran agama Islam (Putra, 2019). Sebagaimana didukung oleh teori bahwa:

"curriculum will be used to refer to the learning experiences of students, in so far as they are expressed on anticipated in good and objectives, plans and design for learning and the implementation of these plans and design in school environments" (Malcolm Skillbeck, 1993). Dalam hal ini menurut Skillbeck, kurikulum digunakan untuk acuan pengalaman pembelajaran siswa, diperlihatkan dalam pembentukan tujuan, rencana, dan rancangan untuk pembelajaran dan pengimplementasian dari rencanarencana tersebut dan rancangan dalam lingkungan sekolah.

Dengan demikian dapat disimpulkan bahwa Hamalik (2004) menyatakan kurikulum memuat isi dan materi pelajaran, merupakan rencana pembelajaran, serta memuat pengalaman belajar. Hal senada dikemukakan oleh Soetopo (2003) yang menyatakan kurikulum adalah semua pengalaman aktual yang dimiliki siswa di bawah pengarahan sekolah. Pendidikan harus mengetahui dan mengembangkan potensi yang dimiliki siswa yang beragam. Kurikulum pendidikan memiliki tugas mengembangkan potensi manusia secara maksimal yang terhimpun dalam jasmani dan rohani (Gunawan, 2011). Kurikulum yang dirancang harus dapat mengembangkan potensi siswa. Kurikulum melalui kegiatan pembelajaran diharapkan menggabungkan keseluruhan potensi yang dimiliki oleh siswa. Saylor dan Alexander menyatakan kurikulum bukan hanya menyangkut matapelajaran yang harus dipelajari tetapi menyangkut seluruh usaha sekolah untuk memengaruhi siswa belajar baik di dalam maupun di luar kelas bahkan di luar sekolah asalkan kegiatan tersebut berada di bawah tanggung jawab guru (Saud, 2008). 
Kurikulum tidak akan lepas dari yang namanya tahap perencanaan, pelaksanaan dan evaluasi. Tahap perencanaan bertujuan untuk menguraikan visi dan misi atau mengembangkan tujuan implementasi yang ingin dicapai. Tahapan pelaksanaan bertujuan untuk melaksanakan blue print yang telah disusun dalam perencanaan dengan menggunakan sejumlah teknik, sumber data yang ada dan telah ditentukan pada tahap perencanaan sebelumnya. Tahap evaluasi bertujuan untuk melihat proses pelaksanaan yang sedang berjalan sebagai tugas kontrol dan melihat hasil akhir yang dicapai (Tatang Hidayat, 2019).

Menurut UU Nomor 20 Tahun 2003, Pendidikan Agama merupakan kurikulum yang harus ada (wajib), baik pada pendidikan dasar, pendidikan menengah maupun pendidikan tinggi di Indonesia. Adapun ruang lingkup Pendidikan Agama Islam adalah: AlQur'an, Aqidah, Syariah, Akhlak dan Tarikh. Hal ini menggambarkan bahwa ruang lingkup Pendidikan Agama Islam mencakup perwujudan keserasian, keselarasan dan keseimbangan hubungan manusia dengan Allah swt, diri sendiri, sesama manusia, makhluk lainnya maupun lingkungannya atau hablun min Allah dan hablun min annas. Dengan demikian cakupan Pendidikan Agama Islam meliputi dimensi kesalehan pribadi, kesalehan sosial juga dimensi kesalehan lingkungan. Sebagaimana dasar dari kurikulum SAL dikatakan bahwa langkah dalam mengembangkan sebuah kurikulum itu juga pengaruhi oleh dimensi masyarakat, peserta didik itu sendiri, juga disiplin pengetahuan. Menurut Harrick, sabagaimana dikutip oleh Hamalik bahwa sumber kurikulum itu ada tiga yaitu; pertama, pengetahuan sebagai sumber yang akan disampaikan kepada anak yang disajikan dari berbagai bidang studi, kedua, masyarakat sebagai sumber kurikulum di mana sekolah merupakan agen masyarakat dalam meneruskan warisanwarisan budaya serta memecahkan masalah-masalah dalam masyarakat. Dan ketiga, individu yang didik sebagai sumber kurikulum di mana kurikulum disusun dengan maksud untuk membantu perkembangan anak seoptimal mungkin (Bahri, 2017).

Kurikulum Pendidikan Agama Islam adalah bahan-bahan pendidikan agama berupa kegiatan, pengetahuan dan pengalaman yang dengan sengaja dan sistematis diberikan kepada anak didik dalam rangka mencapai tujuan pendidikan agama. Menurut pengertian ini kurikulum Pendidikan Agama Islam mencakup pendidikan berkaitan dengan aspek kognitif, aspek afektif dan aspek psikomotorik yang dirancang dan dipilih sekolah dalam rangka mencapai tujuan Pendidikan Agama Islam (Nasron HK, 2017)

Adapun ciri-ciri kurikulum Pendidikan Agama Islam, antara lain: 1). Harus mengedepankan mata pelajaran akhlak, agama dan akhlak yang bersumber dari AlQur'an dan Hadits beserta teladan tokoh-tokoh terdahulu yang sholeh. 2). Harus memperhatikan pengembangan menyeluruh aspek pribadi siswa, yaitu aspek jasmani, akal, dan rohani. Kurikulum Pendidikan Islam memperhatikan keseimbangan antara pribadi dan masyarakat, dunia dan akhirat; keseimbangan yang bersifat relatif karena tidak dapat diukur secara obyektif. 3). Harus memerhatikan ketrampilan, yaitu; seni, pahat, kaligrafi, gambar dan sejenisnya. Selain itu pendidikan jasmani, latihan militer, teknik, ketrampilan, dan bahasa asing. 4). Harus melihat aspek kemajemukan kebudayaan (Zaman, 2019).

Pengembangan materi pendidikan Islam bukanlah sekedar untuk menggabungkan muatan materi pendidikan agama dan umum seperti yang disinggung atau banyak dilakukan banyak orang. Pemahaman seperti itu justru dapat membawa muatan kurikulum pendidikan Islam di samping sangat padat, sehingga mengakibatkan para siswa merasa sulit untuk mengikuti materi tersebut. Sepatutnya para ahli yang terlibat dalam merumuskan kurikulum harus menyesuaikan dengan kebutuhan peserta didik yang nantinya akan membangun negara dan mampu bersaing dalam ilmu pengetahuan dan membawa kedamaian. Oleh karena itu, tuntutan utama dalam pengembangan materi pendidikan Islam, bukanlah materi yang padat, lebih dari itu adalah kemampuankemampuan yang membawa siswa menguasai ketrampilan hidup (life skill) yang Islami. Hasil Studi Litbang Agama dan Diklat Keagamaan tahun 2000, tentang merosotnya moral dan ahlak peserta didik adalah: (a) Kurikulum PAI terlalu padat materinya dengan mengedepankan aspek pemikiran dibanding membangun kesadaran keberagamaan yang utuh. (b) Metodologi PAI kurang mendorong penjiwaan terhadap ajaran agama dan terbatasnya buku-buku keagamaan yang mampu membangun kesadaran beragama dan mendorong perilaku bermoral dan berahlak. Pelaksanaan kegiatan pendidikan agama Islam yang selama ini lebih cenderung bersikap menyendiri, dan kurang adanya interaksi dengan kegiatan pendidikan lainnya. Contoh shalat dhuhur atau ashar yang harus dilaksanakan secara berjama'ah, maka yang dilibatkan dalam mengawasi dan mendampingi para siswa-siswi adalah seluruh guru, baik guru agama maupun guru non agama (Romlah, 2011).

Pendidikan agama Islam juga dalam prakteknya masih menekankan pada aspek kognitif semata dari pertumbuhan kesadaran dan nilai-nilai agama mengabaikan pembinaan aspek afektif dan psikomotorik yang menekankan pada transfer of value (alih nilai). Dengan pendekatan lain, pendidikan agama lebih berorientasi pada belajar tentang agama, dan kurang berorientasi pada belajar bagaimana cara beragama yang benar, bagaimana cara berperilaku yang benar, contoh simplenya bagaimana terdidik tau tata cara sholat yang benar serta menimbulkan feedback dari keresahan apa yang dialami. Kurikulum yang berbasis budaya lokal yang dapat diterima oleh siswa dan memenuhi kebutuhan siswa.

Model kurikulum saylor, alexander dan lewis merupakan perencanaan yang diarahkan pada sekumpulan kesempatan aktivitas pembelajaran bagi individu agar menjadi terdidik. Jadi tidak hanya sekedar dokumen saja. Yang mana mempunyai empat konsep diantaranya yaitu kurikulum sebagai kesempatan belajar terencana, yang mana dengan program ini para terdidik melakukan berbagai kegiatan belajar, sehingga terjadi perubahan dan perkembangan tingkah laku siswa, sesuai tujuan pendidikan dan pembelajaran. Dengan kata lain sekolah menyediakan lingkungan belajar bagi siswa baik di sekolah maupun di luar sekolah. Oleh sebab itu kurikulum disusun sedemikian rupa agar maksud dan tujuannya tercapai. Yang kedua kurikulum sebagai pengalaman, yang mana kegiatan kurikulum tidak terbatas dalam ruang kelas saja, melainkan mencakup juga kegiatan-kegiatan di luar kelas.

Dengan adanya beberapa konsep tersebut dalam pengembangan model SAL pengalaman belajar sangat sangat berpengaruh dan berkontribusi terhadap pertumbuhan dan perkembangan belajar. Begitu juga dalam pendidikan agama islam, pengalaman dan kebiasaan sangat mempengaruhi terhadap kesadaran individu bahwa Pendidikan Agama perlu menggunakan beberapa pendekatan itu. Yakni memberikan pengalaman keagamaan kepada peserta didik dalam rangka penanaman nilai-nilai keagaamaan dan memberikan kesempatan kepada peserta didik untuk senantiasa mengamalkan ajaran agamanya.

\section{KESIMPULAN}

Kurikulum juga dapat diartikan sebagai sebuah rencana menganai tujuan belajar, kompetensi yg ingin dicapai, materi dan hasil belajar yg diharapkan sebagai landasan dan pedoman untuk mencapai kompetensi mendasar dan tujuan dari pendidikan. Saylor, Alexander dan lewis mendefinisikan kurikulum sebagai perangkat/langkah rencana yang diarahkan pada sekumpulan aktivitas pembelajaran bagi individu agar menjadi terdidik. Bahwa kurikulum ialah sebagai sistem dari proses pendidikan yang bersifat luas. Kurikulum memuat tujuan, pengalaman belajar yang harus dimiliki setiap siswa serta berbagai fasilitas yang mendorongnya. Pengembangan kurikulum (curriculum development) didefiniskan sebagai sebuah proses yang kompleks dalam menilai kebutuhan, mengidentifikasi hasil belajar yang diinginkan, mempersiapkan pembelajaran untuk mencapai hasil belajar, dan 
memenuhi kebutuhan pribadi, budaya, sosial yang harus penuhi oleh kurikulum. Oleh karena itu, Kurikulum sebagai system dari proses pendidikan yang bersifat luas, memiliki kedudukan yang sangat strategi dalam keseluruhan pendidikan, bahkan juga tidak akan lepas dari yang namanya tahap perencanaan, pelaksanaan dan evaluasi.

Model pengembangan kurikulum apapun bentuknya tidak boleh kehilangan makna pendidikan agama Islam. Dalam pengembangan kurikulum tidak dapat lepas dari berbagai faktor maupun aspek yang mempengaruhinya, seperti cara berpikir, sistem nilai (nilai moral, keagamaan, politik, budaya, dan sosial), proses pengembangan kebutuhan peserta didik, lingkup (scope) dan urutan (sequence) bahan pelajaran, kebutuhan masyarakat maupun arah program pendidikan. Sebagai salah satu variabel yang mempengaruhi sistem pendidikan, maka kurikulum harus dapat mengikuti dinamika yang ada dalam masyarakat. Kurikulum harus bisa menjawab kebutuhan masyarakat luas dalam menghadapi persoalan kehidupan yang dihadapi.

Pendidikan agama islam merupakan pendidikan yang bertujuan untuk membina dan mengembangkan potensi manusia baik secara individu maupun kelompok sesuai dengan situasi psikologis terdidik. Sebagaimana tujuan dari pendidikan agama Islam yaitu memahami ajaran agama Islam melalui pembinaan dan pengamalan berbagai ilmu pengetahuan sehingga selanjutnya dapat tercermin dalam setiap tingkah laku kepribadian peserta didik.

Model pengembangan SAL ada empat langkah; goals and objectives, curriculum design, curriculum implementation and curriculum evaluation. Dalam mengembangkan sebuah kurikulum itu juga pengaruhi oleh dimensi masyarakat, peserta didik itu sendiri, juga disiplin pengetahuan. Sementara itu model pengembangan kurikulum SAL memiliki beberapa karakteristik pengembangan kurikulum yang bagus. Berdasarkan pandangan komprehensif terhadap setiap kegiatan yang direncanakan, kurikulum berupaya menggabungkan ruang lingkup, rangkaian, interpretasi, keseimbangan subject matter, teknik mengajar, dan hal lain yang dapat direncanakan sebelumnya. Model dalam kurikulum SAL ini sangat masuk dalam proses pembelajaran PAI di pendidikan formal, yang mana sebagai upaya sekolah untuk mempengaruhi siswa agar menumbuhkan semangat belajar, baik dalam ruangan kelas, di halaman sekolah, maupun di luar sekolah. Oleh karena itu lewat model dalam kurikulum SAL berupa pengembangan diri, kompetensi sosial, kemampuan belajar berkesinambungan dan spesialisasi ini diharapkan pendidikan agama Islam mampu meningkatkan kompetensi dalam segala bidang terutama pendidikan, bersifat menyeluruh sehingga dapat digunakan sebagai pedoman hidup dan amalan perbuatannya, baik dalam hubungan dirinya dengan Allah SWT, hubungan dirinya dengan masyarakat maupun dirinya dengan alam sekitar. Selain itu pendidikan Islam harus senantiasa hidup dalam setiap komponen masyarakat.

\section{Referensi}

Adirika, B. N., \& Okolie, V. C. (2016). Examining Models Of Curriculum Development And Processes: Implications For African Educational Heritage And Review. Social Science and Humanities Journal, 1(5), 295-313.

Adnan, M. (2017). Evaluasi kurikulum sebagai kerangka acuan pengembangan pendidikan islam. Al-Idaroh: Jurnal Studi Manajemen Pendidikan Islam, 1(2), 108-129.

Ahid, N. (2006). Konsep dan teori kurikulum dalam dunia pendidikan. ISLAMICA: Jurnal Studi Keislaman, 1(1), 12-29.

Ali, M. (1985). Pengembangan Kurikulum di sekolah. Sinar Baru

Astuti, R. P. (13 September 2019). Meningkatkan Semangat Belajar Siswa Melalui Outdoor Study. Kudus: Jawa Pos Radar Kudus

Bahri, S. (2017). Pengembangan Kurikulum Dasar dan Tujuannya. Jurnal Ilmiah Islam Futura, 11(1), 15-34.

Budianto, E. W. (2019). Inovasi Kurikulum Pesantren. Transformasi: Jurnal Studi Agama Islam, 12(2), 52-67.

Chanifudin, C., Nuriyati, T., \& Harahap, N. (2020). Rekonstruksi Kurikulum Pendidikan Islam (Analisis Pengembangan dan Materi Pendidikan Islam). Akademika: Jurnal Keagamaan dan Pendidikan, 16(1), 71-85.

Coffman, C. (1981). Curriculum Planning for Better Teaching and Learning, By J. Galen Saylor, William M. Alexander, and Arthur J. Lewis. New York: Holt, Rinehart and Winston, 1981. NASSP Bulletin, 65(448), 109-110.

Daud, D., Ahmad, H., \& Johari, H. (2012). Oliva model in malaysian logistics curriculum: a conceptual framework paper. International Journal of Learning and Development, 2(3), 217-228.

Hidayat, T., Firdaus, E., \& Somad, M. A. (2020). Model Pengembangan Kurikulum Tyler Dan Implikasinya Dalam Pembelajaran Pendidikan Agama Islam Di Sekolah. POTENSIA: Jurnal Kependidikan Islam, 5(2), 197-218.

HK, H. N. (2015). Pola Pengembangan Dan Evaluasi Kurikulum Pendidikan Agama Islam. Nuansa: Jurnal Studi Islam dan Kemasyarakatan, 8(2), 195-204.

Husniyah, N. I. (2015). Religious Culture dalam Pengembangan Kurikulum PAI. Akademika, 9.

Indrawati, Y. D. S. I. (2019). Implementasi Kurikulum di Perguruan Tinggi. Al-Kahfi: Jurnal Pendidikan Agama Islam, 4(2), 138-150.

Isri, S. (2015). Konsep Pendidikan Jerman dan Australia; Kajian Komparatif dan Aplikatif terhadap Mutu Pendidikan Indonesia. Jurnal Pendidikan Islam, 4(1), 25-47.

Kusumastuti, M. K., \& Lisnawati, S. (2018, July). Evaluasi Pelaksanaan Kurikulum Pendidikan Agama Islam (PAI) SMA Negeri 1 Bogor. In Annual Conference on Madrasah Studies (Vol. 1, No. 1, pp. 89-99).

Lase, F. (2015). Dasar Pengembangan Kurikulum Menjadi Pengalaman Belajar. Jurnal Obsesi: Jurnal Pendidikan Anak Usia Dini, 1(2), 130-140.

Lunenburg, F. C. (2011). Curriculum development: Inductive models. Schooling, 2(1), 1-8.

Masykur, R. (2019). Teori Dan TelaahPengembangan Kurikulum. In Aura Publisher (Issue September).

Mubasyaroh, M. (2013). Pendidikan Penanaman Sistem Nilai Dalam Pembelajaran Aqidah Akhlaq. Edukasia: Jurnal Penelitian Pendidikan Islam, 8(2), 291-310.

Mulyana, A. T. (2018). Model Pengembangan Bahan Ajar Bahasa Indonesia sebagai Mata Kuliah Wajib Umum (MKWU) Berbasis Paradigma Pembelajaran Abad Ke-21 pada Aspek Career and Life Skills (CLS). Jurnal Inovasi Pendidikan MH Thamrin, 2(2), 4354.

Mutmainah, H., \& Mufid, M. (2018). Upaya Guru PAI dalam Peningkatan Kecerdasan Emosional dan Spiritual Peserta Didik di SMAN 1 Bojonegoro. AT-TUHFAH: Jurnal Studi Keislaman, 7(1), 80-95. 
Putra, P. H. (2019). Tantangan Pendidikan Islam dalam Menghadapi Society 5.0. Islamika: Jurnal Ilmu-Ilmu Keislaman, 19(02), 99110.

Romlah, R. Implementasi Model Pembelajaran Pendidikan Agama Islam Dengan Pendekatan Kontekstual Sebagai Upaya Meningkatkan Kualitas Pembelajaran Di SMP Negeri 13 Kota Malang. Progresiva, 5(1), 162355.

Wafi, A. (2017). Konsep dasar Kurikulum Pendidikan Agama Islam. EDURELIGIA: Jurnal Pendidikan Agama Islam, 1(2), $133-139$.

Winarso, W. (2015). Dasar Pengembangan Kurikulum Sekolah.

Yu'timaalahuyatazaka. (2016). Model Pengembangan Kurikulum Hilda Taba dan Identifikasinya Dalam Kurikulum Pendidikan Islam. Jurnal Manajemen Pendidikan Islam, 4, 138-148.

Zaman, M. K. (2019). Pengembangan Kurikulum PAI Berbasis Kemajemuka. Edupedia: Jurnal Studi Pendidikan dan Pedagogi Islam, $3(2), 43-49$. 